\title{
Queer Pilgrimage: The San Francisco Homeland and Identity Tourism
}

\author{
Alyssa Cymene Howe \\ University of New Mexico
}

\section{Introduction: My Love Waits There}

The loveliness of Paris seems somehow sadly gay

The glory that was Rome is of another day

I've been terribly alone and forgotten in Manhattan

I'm going home to my city by the Bay

I left my heart in San Francisco

High on a hill, it calls to me

To be where little cable cars climb half way to the stars

The morning fog may chill the air

I don't care

My love waits there, in San Francisco, above the blue and windy sea

When I come home to you, San Francisco, your golden sun will shine for me

- "I Left My Heart in San Francisco," music by George C. Cory Jr., lyrics by Douglass Cross, sung by Tony Bennett

The crowd was silent and transfixed as Tony Bennett began to croon his rendition of "I Left My Heart in San Francisco." Surrounded by the thousands who had come to baptize the Virgin MegaStore in downtown San Francisco, Bennett concluded his ditty to much applause. The song has become a kind of unofficial anthem for the City of San Francisco since it was made popular by Bennett in the early 1960s. However, the tune was written by a gay couple having recently moved from the city (Hobica 1995:190). The links among San Francisco, queer people, and the lure of a "homeland" have been a long time in the making.

Anthropologists have, for decades, noted how places are made mythical through the telling of stories and the singing of songs. Anthropologists have also, more recently, assessed how places are made mythical through anthropologists' retellings of stories and analyses of songs (Castañeda 1996; Clifford and Marcus 1986). Because San Francisco has enjoyed a long history of mythologizing embodied in songs such as "I Left My Heart in San Francisco," the following will also add to the legacy of stories about places and how people conceive of those places. In the popular imagination, the city is often proclaimed 
the "world's gay and lesbian capital" (Apell 1998:94). This sense of a "capital," I will suggest, is more accurately described as a territorial "homeland." While capitals are the legislative nexuses of states, homelands of fer a symbolic refuge for believers who make the pilgrimage. The focus of my discussion will be to elaborate some of the elements that foster the construction of San Francisco as a queer homeland. Borrowing from de Certeau (1984), I hope to elaborate the "scriptural economy" through which "the multiple levels and contexts of cultural-ideological productions" (Castañeda 1996:65) shape the notion of a queer homeland. Through ethnographic narratives, touristic ephemera, and gay tour guidebooks, ' I address the following questions: How is San Francisco constructed as a pilgrimage site for the elaboration of queer identity, and how might this sense of a homeland emerge over time and through "touristic" practices? Does a queer homeland rely on "staged" authenticity, the "backstage" only available to some? Further, how might nationalist-like tropes foster the construction of a territorial homeland for a queer nation." Finally, how does queer group identity differ from nationalisms that are dependent on imagined primordial conscription?

In this article, I frame the construction of a queer homeland through the phenomenon of tourism. Tourism offers a rich set of juxtapositions because the interplay between tourists and residents illustrates the complexity of creating place, locality, and a sense of homeland. I also suggest that, in the case of San Francisco, tourism is critical to creating a sense of group identity for both tourists and residents, albeit in different ways. Thus, tourism as a practice that enhances identity is fundamental to the creation of a queer homeland, which relies on "identity" for its production. I further consider the city"s history as integral to its construction as a homeland for queer people, and my theoretical concerns are rendered through a historical lens. The larger theoretical issues that inform my discussion take up the discursive notions of "queer," "identity." and "place." I attempt to resituate these sometimes nebulous terms by applying them to concrete ethnographic examples. Narratives of tourists and residents. as well as the language found in tour guidebooks, suggest an emerging queer homeland that is being constructed through pilgrimage. Tour book discourse. narratives of respondents, and my own interpretive gloss all evidence a slippage among categories of "gay," "lesbian," and "queer." I focus attention on a specifically "queer" homeland in order to suggest a more complex articulation of group identity than that allowed by gay and lesbian. Queerness moves beyond homogeneous identity categorization, which. I will argue. is fundamental to the creation of a homeland in San Francisco. Thus. part of my project throughout this discussion will be to highlight the multivocality that arises in attempting to grasp the panoply of sexual identities I gloss as "queer."

I maintain a particular focus on fissures of age. gender, race, and class status within a queer whole, and I argue that these factors evidence a break in queer coherence. a rip in the umbrella term that underscores the ongoing reformulation of queerness. By mapping sex onto sites. linking gazes with voyeurs, and politicizing place, I attempt to move away from essentialized constructions 
of queerness. Instead, I suggest that the differential marking of bodies and queer consumption among residents and tourists illustrate a continuum of sexual fluidity that marks San Francisco itself as an explicitly queer place. This discussion is complicated by my own position as a former longtime resident and occasional tourist to the city. I recognize that my "voice" often seamlessly slips between that of activist and that of analyst. Because queers have been persecuted many times in many places, 1 believe that territorializing a place, a homeland, can offer a sanctuary from oppression. Although I acknowledge this slippage between the positions of advocate and anthropologist, I have chosen not to erase this dynamic but, rather, to highlight its potential to add yet another dimension in the making of a homeland.

\section{Touring the. Town: Identity Migration}

Tourism considered as an economic and ideological endeavor (MacCannell 1976; Rothman 1998; Urry 1990) informs how representations of the city are constructed by the purveyors of "gay tourism" and highlights how these representations are received by both gay tourists and gay residents of San Francisco. Tourism, as a "privileged practice" (Towner 1985) of the economically endowed, is inverted when considering a distinctly marginalized group such as gays and lesbians because tourism is, as the Turners (1978) have argued, linked to older forms of pilgrimage to the world religious centers. ${ }^{3}$ Tourism, like pilgrimage, has a "magic" that is "enhanced by group identity" (Graburn 1989:34), which may prove even more magical when it is tourism itself that congeals group identity - which I argue is the case in San Francisco's queer homeland. ${ }^{4}$ Queer tourists leave "home," where they may not be accepted based on their sexual identity, in order to come to a "homeland" where they are accepted. The medium of tourism illustrates an uneven "emergence" of a homeland, rather than an essential, "authentic" homeland. "Staged events" (MacCannell 1976) and "pseudo-events" (Boorstin 1964) have been described as those fabrications designed to create a more "authentic" experience for "moderns" in search of escape. However, in a pilgrimage to a queer homeland. the generalized escapism of modernity is interwoven with an acute need, at times, for queer people to literally "escape." Because the queer pilgrim does not seek an escape from the modern but, rather, an escape from oppression "back home," notions of "staged" and "pseudo-events" are less germane. Rather, I invoke Castañeda's "imagined understanding of experience" (1996:17) to illuminate how an essentialized "gay authenticity" appears in the narratives of queer tourists and residents. In the elahoration of queer identity, essentialized meanings seem 10 facilitate a sense of membership in a larger queer nation-“imagined" or otherwise. Queer discourses of membership resemble nationalist discourses but also depart from them, particularly when factors of gender, class. and race are brought to the fore. For queers, a "homeland" comprises many voices, built consciously and unconsciously through diverse practices over time. 


\section{Moving through History}

The historical and cultural nuance of "moving" holds particular significance for an immigrant city such as San Francisco. ${ }^{5}$ Kaplan has suggested that in narratives of "modernist exile" and "postmodern tourism," it is "modern cities, especially major ports, [that] function as crucibles where identities are formed, transformed, and fixed" (1996:31). Similarly, Weston (1998) elaborates how gay migrants from rural areas and small towns sought the anonymity of urban centers, thus facilitating the creation of a "gay imaginary." According to Weston, this imaginary made San Francisco "the premier destination" for identity migrants such as gays, lesbians, and "explorers" of sexuality (1998:32) to create subjectivities based on identification with "others like me." However, many historical sequences preceded the making of the homeland and intimately informed the imagining that would follow. San Francisco's past foreshadowed the representation of the city as a place of nonconformity; this nonconformity would later be transformed into an imagined gay mecca.

Weston situates the Great Gay Migration in the 1970s and early 1980s. But it is also the case that San Francisco served as a crucible for subversive identities dating back to the city's boom era in the mid-1800s. The discovery of gold in the northern reaches of the state ushered in an age of pioneering men in search of fortune. The gold rush lured a huge, predominantly male population to San Francisco following in the wake of mission building and the near decimation of indigenous peoples. ${ }^{7}$ Tales of the city's early days, in the 1850 s, refer to the absence of women; when a woman did appear, she was greeted by hundreds of leering men intent to gaze on the female form. Word throughout the nation was that the city was a new frontier for the entrepreneurial man willing to leave the securities of home and hearth behind. Wealth was extracted from the earth, funneled into the city, and used in the service of decadence: drinking, gambling, and carousing. Fortunes were spent in the building of railroads and the development of agriculture, ${ }^{8}$ as immigrant laborers, primarily young Chinese men, were encouraged to lend their hands and backs to the city's growth. ${ }^{9}$ Immigration legislation was fed by a racism that considered Chinese immigrants a viable source of labor but an inappropriate group to propagate and settle in the city. Chinese women were forbidden from immigrating to California, which served to increase the predominance of a male population. This much disseminated "origin story" of the city is one rooted in a nearly single-gendered population with a taste for decadence. Although this alludes to a sense that heteroreproductive norms would not prevail in the city. I contend that other factors would create San Francisco's reputation as a crucible for nonconformity.

I highlight the gold rush and its effects in order to make clear that San Francisco has been associated, since its inception, with an irreverence for dominant notions of home and heteronormativity. Gold rush immigration patterns were distinct from previous Western migrations, primarily because. unlike their agricultural counterparts. large families were not necessary to "strike it rich" in California. Although white settlers in the city held more power over 
their destinies than the Chinese immigrants, each group comprised, for some time, males only. Shiploads of Navy men on leave heightened the reputation of the city as a locale for tattooing, drinking, and other forms of decadence. This nonconformist irreverence, or "cultural libertarianism" (Bean 1968:448), surely inspired such characters as Jack London and, later, Jack Kerouac and friends to make an intellectual and artistic refuge of the city. ${ }^{10}$

\section{Queer Moments in San Francisco}

In the early part of the century, San Francisco gay bars were populated by travelers from across the country, and significant political organizing began to take place in the 1950s. ${ }^{11}$ World War II drew thousands of workers to the urban centers of the West Coast, where gay enclave communities were quickly being established (Faderman 1991). After the war the military imposed more virulent restrictions on gay personnel, and many were loaded onto "queer ships" along with other "undesirable" discharges and sent to nearby port cities such as San Francisco. Indeed, ironically, the U.S. government seems to have "sponsored a migration of the gay community" (Berubé 1982). The burgeoning growth of gay enclave communities in the postwar era, the free speech movement, protests against U.S. involvement in Vietnam, and hippie counterculture blossoming in the Haight Ashbury District all demanded diverse freedoms. The 1967 Love Generation musical hit "San Francisco (Be Sure to Wear Flowers in Your Hair)" may have signified the full bloom of hippie culture, but gay San Francisco was already there. Indeed, Fitzgerald (1986) has suggested that the Castro, "the first gay neighborhood in the country," arose singularly from an already extant counterculture.

Countercultural tendencies informed the construction of San Francisco as a particularly hospitable locale for the thousands of gay people who flocked to the Castro District in the 1970s. However, this phenomenon must be understood as a complex set of factors, not simply the "natural" evolution of counterculture. ${ }^{12}$ In particular, progressive ideals of "tolerance" have long defined the city's political atmosphere and form a part of the city's symbolic construction. Some have suggested that San Francisco "was America's gay capital in terms of political clout" (Newton 1993:9), marking the city as not merely a haven but an explicitly political place. ${ }^{13}$ Progressive politics appears to be a key element in the formation of a gay homeland, and San Francisco was the first city in the nation to elect an "out" gay official. ${ }^{14}$ Antigay legislation spearheaded by the religious Right spread across the nation throughout the late 1970s (Vaid 1995). The establishment of the city as a sanctuary for diverse sexual identities has taken place in a larger, hostile terrain: a queer homeland is necessarily built upon uneven ground.

\section{Questioning Queer, Imagining Identity, Politicizing Place}

The complexities of a queer homeland are also revealed in the more mundane, though highly contested, constructions of discourse. In the early 1990s, 
the term queer was popularized partly because it includes gay men, lesbians, bisexuals, transgendered persons, and other "sexual radicals" (those practicing sadomasochism, bondage and discipline, etc.). Queer, a carefully selected discursive appropriation of a derogatory term, includes "faggots" and "fairies" as well as "lezzies" and "dykes" (Faderman 1991:300). Rendering positive those monikers that have been used to abuse is queered thinking, born from real need: "Most societies try to get rid of their deviants. Most cultures have burned and beaten their homosexuals and others who deviate from the sexual common. The queer are the mirror reflecting the heterosexual tribe's fear: being different, being other and therefore lesser, therefore sub-human, in-human, non-human" (Anzaldúa 1987:18). The term queer has served to rally various sexualities under one umbrella "identity," sometimes engendering political coalitions. However, queer is not without its problems. Often, argues Anzaldúa (1991), queer serves to erase differences of race, class, and gender within the gay community, homogenizing differing interests and identities. Further, through neutralizing difference queer may come to be associated with the dominant sector of the community (read: white, wealthy gay men). Despite this potential slippage, Anzaldúa ultimately chooses to use the term queer because other identity monikers, like lesbian, are likewise invested with a dominant, white history. Following Anzaldúa's caveat, I find queer a useful umbrella term while recognizing that all are not equally sheltered under such terms. I would argue that in the making of a queer homeland, validating difference is of critical importance. A homogeneous, one-dimensional sense of queer identity does not appear to serve the purposes of an inclusive homeland.

"Identity" as a useful category of analysis has also been widely critiqued in academic works. B. Williams (1996) has insisted that identity, especially within the frame of nationalism, must be understood as a multiply constituted construct within power relations. As an analytical concept, identity is both complex and shifting. Within people's lived experience, identity may also prove a useful tool for people's self-conceptions. Anderson's discussion of nationalism formation suggests that an imagined "deep, horizontal comradeship" (1983:7) serves as the basis of national "communities." The nation is imagined as a "natural" constellation of persons because it is understood as a limited (though elastic) sovereign group with a shared history and trajectory. By framing queer identity against a backdrop of nationalism, I find similarities: both speak to political aspirations based on a shared sense of identity. However, although membership in a nation can only in certain circumstances be chosen, membership in a queer "nation" is almost certainly chosen. ${ }^{15}$ Further, the parameters of group identity among self-identified queers are infinitely more flexible than those of nations. ${ }^{16}$ Although both forms of "nation" share an "imagined" continuity of identity, the queer nation is not dependent on imagined ties of blood and bone but, rather, on sexual practices, self-conscious forms of marking, and political positioning.

The gay rights movement, since its inception during the civil rights era, has often made use of nationalist and racial tropes (Phelan 1997). These have 
proven effective in building political coalitions and consolidating a sense of community identity. If, as Lanfant, Allock, and Bruner suggest, identity is "always in reformulation, a constant site of struggle" (1995:xi), then the process by which identity takes shape must include reworking, displacement, disruption, and reflexivity. Just as gender identity coincides with factors of race, class status, and others, so too does queer identity reflect a composite, shifting form. This formulation echoes Butler's suggestion that the "doer is constructed in and through the deed" (1990:142) and the subject is constituted by an "incomplete list" (in terms of race, class, sexuality, gender, etc.) and only comes into being as an "I," or an "identity," is named: "In other words, the enabling conditions for an assertion of ' $I$ ' are provided by the structure of signification, the rules that regulate the legitimate and illegitimate invocation of that pronoun, the practices that establish the terms of intelligibility by which that pronoun can circulate" (1990:143):

Places, too, are contested, their borders defined differently based on one's position. To highlight the notion of shifting identities in a queer homeland, I oscillate between places marked as "for women" and "for men" and those marked explicitly by race. Overt gender distinctions, at times, seem antithetical to the project of queering, steeped as they are in binaries and bodily dualisms. However, distinctions continue to be made along these lines by the people with whom I spoke and within queer guidebooks, and so I follow this gendered route. In addition to questioning divisions of gender, race, class, and so on, I hope to problematize the notion of a "queer-only" space by looking to mixedsexuality events and venues. I find "queer only" to be a problematic parameter, given the shifting, voluntaristic characteristics of queer nationhood that I have suggested. The sites I examine in the ethnographic portion of this discussion are those that appear regularly in queer tour guidebooks. They are, therefore, defined as significant locales for queer tourists by those who market to this population. The tour books themselves render a particular conceptual map of San Francisco, highlighting some venues, events, and places while diminishing the significance of others. Although I cannot hope to bring a comprehensive analysis of all of the sociopolitical factors that go into constituting these particular sites as significant to the queer community, I offer instead an examination of these representations as they exist now, remembering that this is a particular map of the heart of queer San Francisco.

\section{Touring a Queer Homeland}

The 1998 San Francisco Pride Parade, held in mid-June on a mile-long stretch through downtown, has drawn hundreds of thousands of visitors, nearly doubling the population of the city. The rambunctious procession is led by Dykes on Bikes with revving engines and lots of leather (see Figure 1). This group is followed by Dykes on Bicycles; taking up the rear is a new addition to the parade, a contingent of the Radical Fairies calling itself Dicks on Bikes. Over the course of the three- or four-hour event a host of queer-positive groups ride atop floats, march, and cheer their way down the parade route. The Philipino 


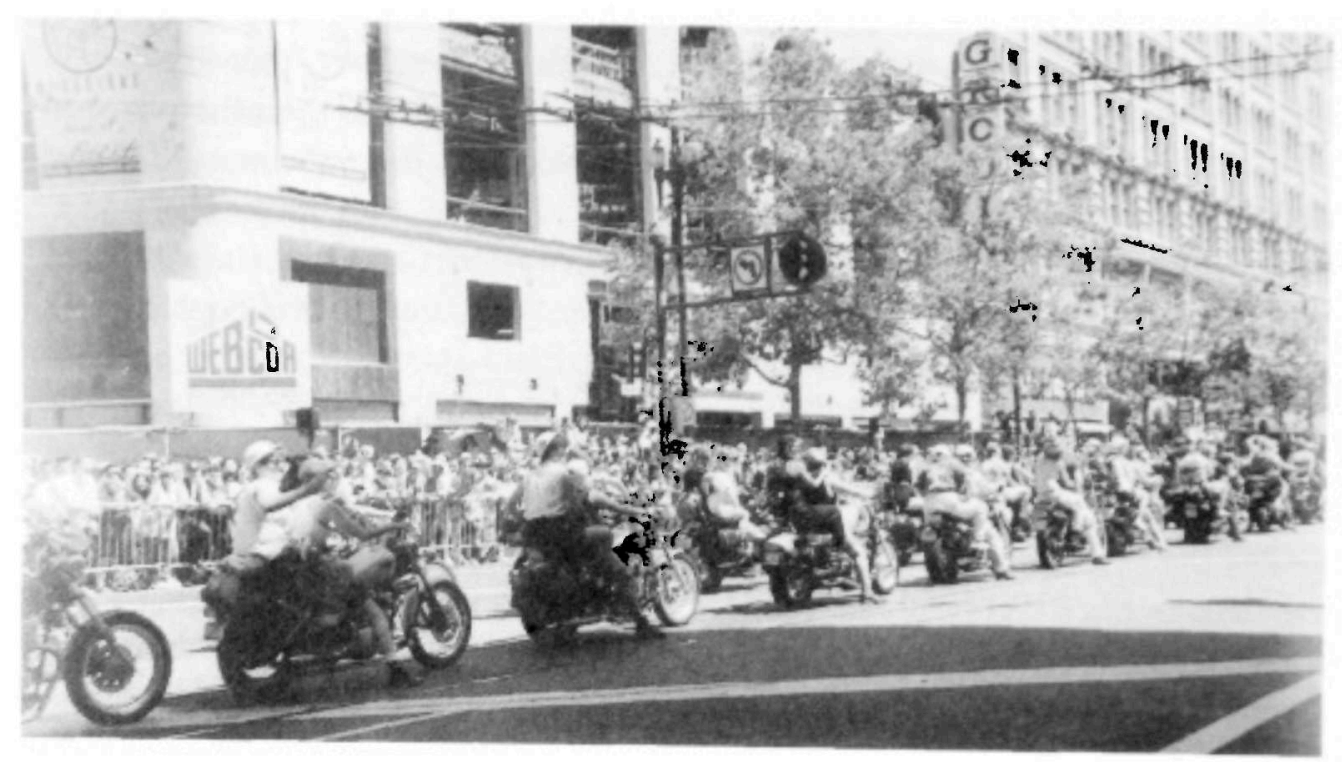

Figure 1

Dykes on Bikes at the Lesbian, Gay, Bisexual, and Transgender Pride Parade, San Francisco, 1998.

Men's Chorus, gay grandparents, Muscle Systems (a.k.a., Muscle Sisters) Gym Boys, and a female-to-male transgendered contingent are a few of the many interests represented in the course of the parade. Parties, dances, and carousing compose what is also known as "Pink Saturday" (see Figure 2). Perhaps more than any event in the city, the Pride Parade serves to consolidate and elaborate queer identity. Through "praying and playing" (Turner and Turner 1978) in the parade. participants perform an expansive queer identity. While "playing" seems obvious here, ${ }^{17}$ "praying" comes in a form particular to a queer "nation." If prayer is understood as a shared practice that aligns individuals with a spiritual deity and the community at large. then activism serves as a form of prayer for a queer nation. Networking. strengthening political alliances, and spending time together all serve to build community and strengthen individuals alliance with a queer whole. The values reflected in respondents narratives speak overwhelmingly to a sense of inclusion in a greater queer community, which seems to live and breath at events such as the Pride Parade ${ }^{18}$ As $\mathrm{L}$. noted. "The thing about San Francisco Pride is that it s political not just a hunch of pretty boys and girls doing their thing but floats and events and all hinds of stuff which focuses on political concerns of the community." L. focused attention on the politics of the Pride event. a critical aspect of queer pilgrimage In pilgrimage. "passengers" engage in a liminal "betwixt and between" state of being. which ends in aggregation. a return to "mundane social life" (Turner and Turner 1978:14). However, in a queer pilgrimage the return is not to a "stable state" but, rather, to one invigorated with new political possibilities. Pilgrimages of all kinds involve personal transformation, ${ }^{20}$ and queer pilgrims returning with 


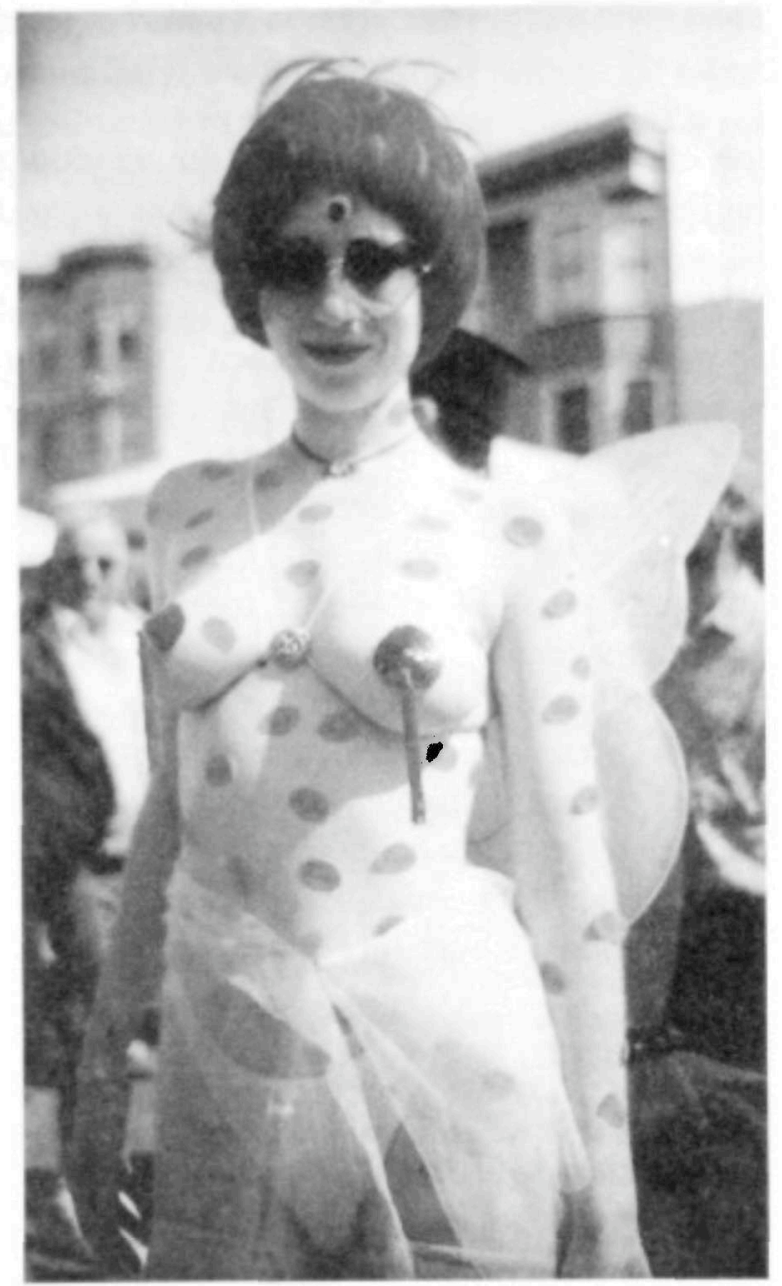

Figure 2

A femme fairy performing on Pink Saturday, San Francisco, 1998. Her lody is adorned with produce stichers that say "Ripe."

new political agendas may upset the "mundane social life" back home. A "transformation of the self" (Bruner 1991). or at least an attempt at transformation. then. is salient for the individual as well as the larger community, adding to the magic of liminality.

At Pride, $Z$. described her sense of solidarity with a ereater queer whole. partly because in this setting she and her girlfiend felt "safe" to do so:

My girlfuend and I live up in Reno, but l used to live here in the cily I re heen out since I was 18. hut [K I has only come out on her sister. Vo one in Reno knows she's a dyke. and the feels bke she can't be out at work. Her parents don i know ether. hut that"s another story. They thunk that I am "a friend" even though we ve been logether for almost two ycars now! Anyhow, when we come wo San Francisco all of that changes My girlficend is out, and 1 get to. finally conoy having a girlfriend who I can hold hands with, and smooch. and dance dirly with in public. I hate being in the closet. and that s how it is in Reno for us. Here we get to be "real." I don't know what I'd do if we didn't have the city to come to. Of course Pride is 
fun and crazy and there are lots of babes, so we always make it down here for this. ${ }^{21}$

Z.'s transformation of "self" took place during the window of liminality she enjoyed during the Pride weekend. Bruner (1991) has suggested that the tourist, despite the claims of tour books and brochures, does not undergo any radical transformation. However, Bruner's argument is predicated on the twin factors of economic power differentials between "the native self" and the "Western tourist" and the proposition that "most tourists are quite satisfied with their own society, most are not alienated" (1991:240). However, Z. clearly felt some form of alienation in her "own society," which she mitigated through liminal experiences in San Francisco.

In Bruner's discussion of "First World" tourists visiting "Third World" touristic sites, there is an explicit "structure of power" mandating that residents cater to the "fantasies" of tourists. However, the converse appears to operate in San Francisco. If only in terms of economics, it would not be out of line to suggest that most residents of the city (which has one of the highest costs of living in the United States) are often better economically endowed than many tourists to the city. Perhaps greater economic parity between tourists and residents lends itself to transformations. It certainly appears to foster solidarity:

I am visiting from Germany, and we do have many gay rights groups there and events. Everyone there talks about San Francisco and about this weekend. I've been hearing about it since I was a teenager and now am finally here, amongst my people, all these beautiful gay people. ${ }^{22}$

This is the biggest of all the Pride events. . . . If you haven't been to S.F. Pride, you can't even call yourself gay! ${ }^{23}$

The refrain of "my people,"24 and the suggestion that one cannot be gay without having experienced San Francisco Pride, lends itself to an overt articulation of nationalist-like community identity. ${ }^{25}$ The emphasis here is on the journey of pilgrimage and experience, rather than (imagined) primordial ties. MacCannell (1976) has described the importance of experience for the modern tourist, for whom a search for "authenticity," often "back there" in space and time, provides a unifying modern consciousness. As these narratives suggest, moderns attempt to reach the "backstages" (Goffman 1959), where "true authenticity" lies, through experience rather than commodification. While queer tourists may never find an authentic backstage-indeed, one may not exist-they do engage in the aesthetic of modernity in their quest for "a more meaningful existence somewhere else" (Kaplan 1996:64). Though modern exiles may seek the aesthetic elsewhere in order to return, rejuvenated, to their origins, this does not appear to hold true for the queer tourist. Queers, who often experience exile from, and ostracism living in, their places of origin (nation-state, community, family, and so on), here find their "return" in a pilgrimage to a homeland. ${ }^{26}$ These narratives and the nationalist-like tropes they embody 
reflect the imagining of a queer homeland in San Francisco. They resonate with a sense of community: a coherent queer whole. However, this coherence is disrupted in the following examples; a queer homeland is not made, it seems, through a monolithic sense of queer identity.

Located in the Castro District is Cafe Flore, known to many queer San Franciscans as "Cafe Hairdoo,"27 where the clientele partakes of skinless chicken breast sandwiches and espresso drinks in a sanctuary-like patio. Café Flore appears in gay guides as a premiere breakfast place for a predominately gay male crowd. Access: Gay USA (Apell 1998), a guide that marks each of its venues with either a male or a female symbol, lists Cafe Flore with a male symbol with an exclamation point next to it, suggesting that this is a "tres gay" male site. Differentiation between male and female sites is a theme that recurs in gay tour guides, emphasizing that gender is an axis of distinction for those constructing gay touristic experiences in the form of gay guides. In a recent glossy tour guide magazine called California: Culture's Edge (California Cultural Tourism Commission [CCTC] 1998), published by the San Francisco Arts Commission, ${ }^{28}$ the section oriented to queer tourists highlights sites that can be visited within a three-day period. The first day's tour is entitled "The Castro." Day two is labeled "Mostly for Women: The Mission." These designations suggest that different neighborhoods will appeal to particular genders within the queer community. However, there is something more here. "The Mission" is described as "for women," whereas "the Castro" remains the unmarked signifier. The Castro, not coincidentally, is a predominately male neighborhood. As with ethnic "unmarked categories," here the dominant gender category, male, remains the a priori category. Anzaldúa's warning that "queer" may become a homogeneous (gay, white, male) category is salient here. Although it might be argued that the Castro District has achieved the status of being "famous for being famous" (Turner and Turner 1978:12), within the queer community the Castro District is famous for being a gathering place of gay men specifically. The Castro and the Mission Districts are represented as specifically gendered places for queer visitors to the city. ${ }^{29}$ Although this does not point to fissures in queer identity per se, it does suggest distinctions in how queer identity is represented, and therefore shaped, for the queer tourist. A singular sense of queerness is elaborated and intersected by other identity factors such as class status and gender through the textual constructions of gay guidebooks.

An event on the eve of Pink Saturday speaks to these differences. The Dyke March, which attracts thousands of women to the Mission for a rally, march, and after party, is a women's event (see Figure 3). Men are encouraged to watch and cheer but not to march. Women, whether they identify as lesbians, dykes, bi, straight, polyamorous, and so forth, parade through the streets holding signs, some semiclothed and some riding atop a gigantic ejaculating vagina. In the past, there has been debate about whether transgender people should participate in the Dyke March. ${ }^{30}$ In the case of female-to-male transgender people, many of whom have been longtime lesbian activists, their previous 


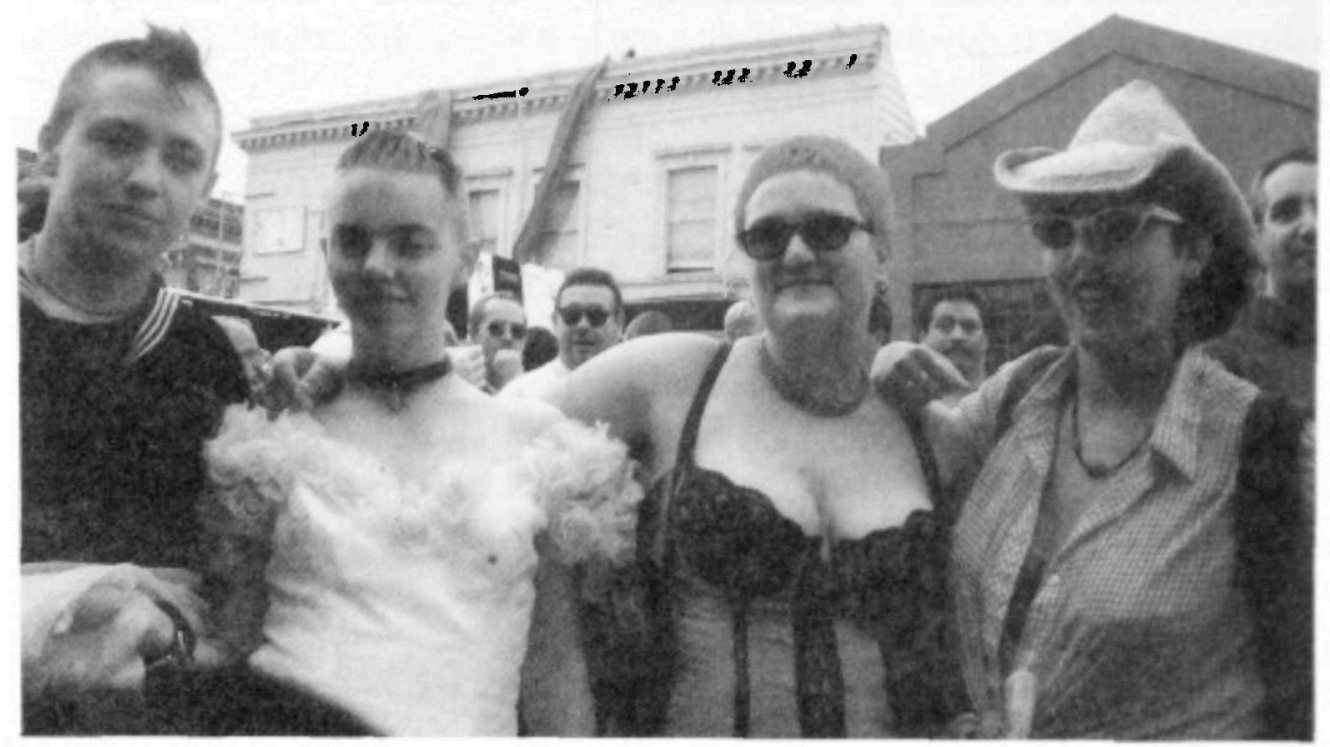

Figure 3

Dyke marchers at the Dyke March, Mission District, San Francisco, 1998.

gender identity and commitment to women's issues would suggest that they should march. while their current gender identity would have them on the sidelines only. For male-to-female transgender people the situation is reversed. with questions of political solidarity arising more readily than issues of gender solidarity. In either case, the debate is complex and speaks to salient distinc tions within the queer community itself. A singular sense of queer identity is problematized, suggesting that qualities other than one's sexual self, such as political and gender allegiance. must be negotiated within the concept of queerness. Indeed, when noting that a woman in the Dyke March proclaimed. "There are thousands of me here!" 31 one wonders it she was speaking about women, or lesbians. or queers, or all of the above

Similar stratifications along lines of race and class appear throughout ga! tour books. Gav USA: The Siraight Talking Gwide of Gay Travel (Hobica 1995) lists topical headings that highlight ethnic identily and income levels The Pendulum, a nightclub in the heart of the Castwo. is billed under the heading "African-American and Latino Bars" as a "place for black men and the men who love them" (Hobica 1995:192). Pleasuredome, under the category "Mostly for Dancing." caters to "young men on drugs" (Hobica 1995:193). and, next to this entry. The. $B o x$ is billed as "racially mixed." I he "young men on drugs" at Pleasuredome may be presumed to be predominantly white because they remain unmarked by race. unlike the patrons at The Pendulum and The $\mathrm{Box} .{ }^{32}$ Interestingly. Pleasuredome does cater to a primarily white clientele. In any case, thesc representations of queer sites reflect overt distunctions based on race. Similarly, the heading "Upscale Crowd" invites queer patrons to 
the Alta Plaza, where suits and $\mathbf{\$ 7 . 0 0}$ martinis are the norm. Differentiations based on race, economic status, and gender riddle the ephemera directed toward the queer tourist. This representational tactic appears to be inclusive, acknowledging the diversity of the queer community. However, these distinctions also make clear that certain dominant categories remain unmarked.

A further line of intraqueer distinction is summarized in an anonymous on-line review of Fodor's Gay Guide to the USA (Collins 1997):

\begin{abstract}
Consider that on page 50 of Fodor's Gay Guide to San Francisco Collins says that many of SF's gay bars cater "mostly to old drunks." He then describes trying to meet someone at one of these bars: "You give him a quick tap on the shoulder, just to see if anybody is in there. And crash! He falls off his bar stool." Later Collins says that there's a bar stool in SF with your name on it, and "all you have to do is try not to fall off it." It's incredible to encounter such blatant ageism. Having just spent time in SF, I can report that one of the city's most refreshing aspects is the diversity of both age and body type in its gay population, a diversity which I've never encountered in any other American city. It's possible to feel comfortable in the Castro and other neighborhoods without being a 22-year-old man with a gym body. Collins may not perceive that as being a strength. Someone should sit Collins down, show him The Times of Harvey Milk, and make him read The Mayor of Castro Street. Then he may learn that those "old drunks" in some cases gave up their lives so that he'd have a bubble of tolerance to play in. [Anonymous 1998]
\end{abstract}

The author illuminates yet another line of distinction within the queer community based on age and body type. Ultimately the author finds San Francisco to be a particularly accepting locale for all manner of queer tourists. The comments extend the frame of queer inclusion, affirming that San Francisco is often characterized as a diverse amalgamation of queer people.

Distinctions of race, gender, class, and age are positioned alongside an oft repeated trope of gay tour guidebooks: sex. Sex penetrates guidebooks presumably because sex, desire, and "object choice" have often been foundational for both forming queer communities and establishing identity for queer people. At the same time, a singular focus on the sexual aspect of sexual identity offers a limited scope of queerness, "essentializing" and "naturalizing" complex subjectivities. In order to distinguish between queer people's lived experience and the representation of their experience and desire in gay tour guidebooks, it is important to establish the relationship between representations of experience and lived experience itself. Although sex alone does not constitute queer identity, and political motivations are vital to constructing a queer nation, it would be foolish to obscure the "communitas" engendered through cruising and coupling. This element of queer identity is not lost on the creators of queer touristic ephemera. Overt sexual references categorize venues as places for "Cruising and Drinking," getting into" "Leather," or, for the very explicit, "Sex Clubs" (Hobica 1995:243-245). The heading "Top Tables" (Hobica 1995:243, emphasis added) highlights restaurants that serve expensive cuisine. However, Hobica's word choice here, in the context of leather and sex clubs, invokes the age-old food/sex correlation. Using the jargon of domination and submission, Hobica 
manages to couple gastronomy with radical sexual positionings. "Mostly for Dancing" (Hobica 1995:193, emphasis added) leaves the reader $k$ ondering what else might go on here. Sexual references throughout queer tour guides, some more veiled than others, emphasize the sexual aspect of representing sexual identity. To ironically twist Graburn's (1989) "sacred and profane," one might say that what is "profane" by normative standards is in fact "sacred" to a queer homeland. Heteronormative sentiments often maintain that "homosexuals [are] deviant, immoral individuals ... [who] simply live an aberrant lifestyle rather than constituting a legitimate cultural identity" (Irvine 1998:575). Thus, the overt representation of queer sexual behavior throughout these guides suggests a distinct reverence for sexual behaviors that are stigmatized in heteronormative discourses.

Discussing the representation of Amsterdam as "the Gay Capital of the World," Dahles describes the contentious debates among the city's tourism boards as to whether Amsterdam's image should be that of "history" or that of "heretics and whores" (1996:231). The representation of San Francisco as an explicitly sexual gay mecca has met with similar obstacles. The director of the San Francisco Arts Commission explained that in composing the three-day tours to be represented in California: Culture's Edge, he contended with individuals from the San Diego Arts Commission who did not agree that a "Pride" tour should be included in the magazine. ${ }^{33}$ The "Pride" tour was ultimately included because, in the director's words, "I could not face my constituency in San Francisco and tell them that a gay and lesbian tour had not been included." Those creating the representations of both Amsterdam and San Francisco have grappled with the cities' sexual "stigma" and the stigma of homosexuality in particular. Both Amsterdam and San Francisco continue to be linked with sexuality in the popular imagination, often through particular sites.

Josie's Cabaret and Juice Joint is situated in the nexus of the Castro/Market Street area and packs its sunny back patio with a late breakfast crowd. Vegetarian fare constitutes the menu, and the artwork of HIV+ people covers the walls. In the evenings, campy shows and comedians entertain audiences who sip ginger ale and espresso. Josie's is consistently mentioned in gay tour guidebooks among the "10 things no self respecting gay person should miss" (Hobica 1995:189). Josie's is also consistently mentioned in nonqueer guides to the city as a "must see" that is "highly recommended. ${ }^{.34}$ Josie"s appearance in a diversity of guides brings to light two issues in the construction of a queer homeland. First, the fact that Josie's appears in nonqueer guides suggests that queer entertainment and perhaps queer people themselves are considered one of the many "attractions" of the city. Queer people, in this sense, are portrayed to a nonqueer audience as suitable objects of the "tourist gaze" (Urry 1990). Gazing tourists attempt to appropriate "authentic others" in order to sidestep modernity. Perhaps the very spectacle of queer performativity. in all its flamboyance, invites a voyeuristic crowd of heterosexual gazers. Perhaps vivid performances of "queer identity" (see Figure 4) are viewed as a product to be consumed, the "sexual other" taking the place of the "primitive other." However, 


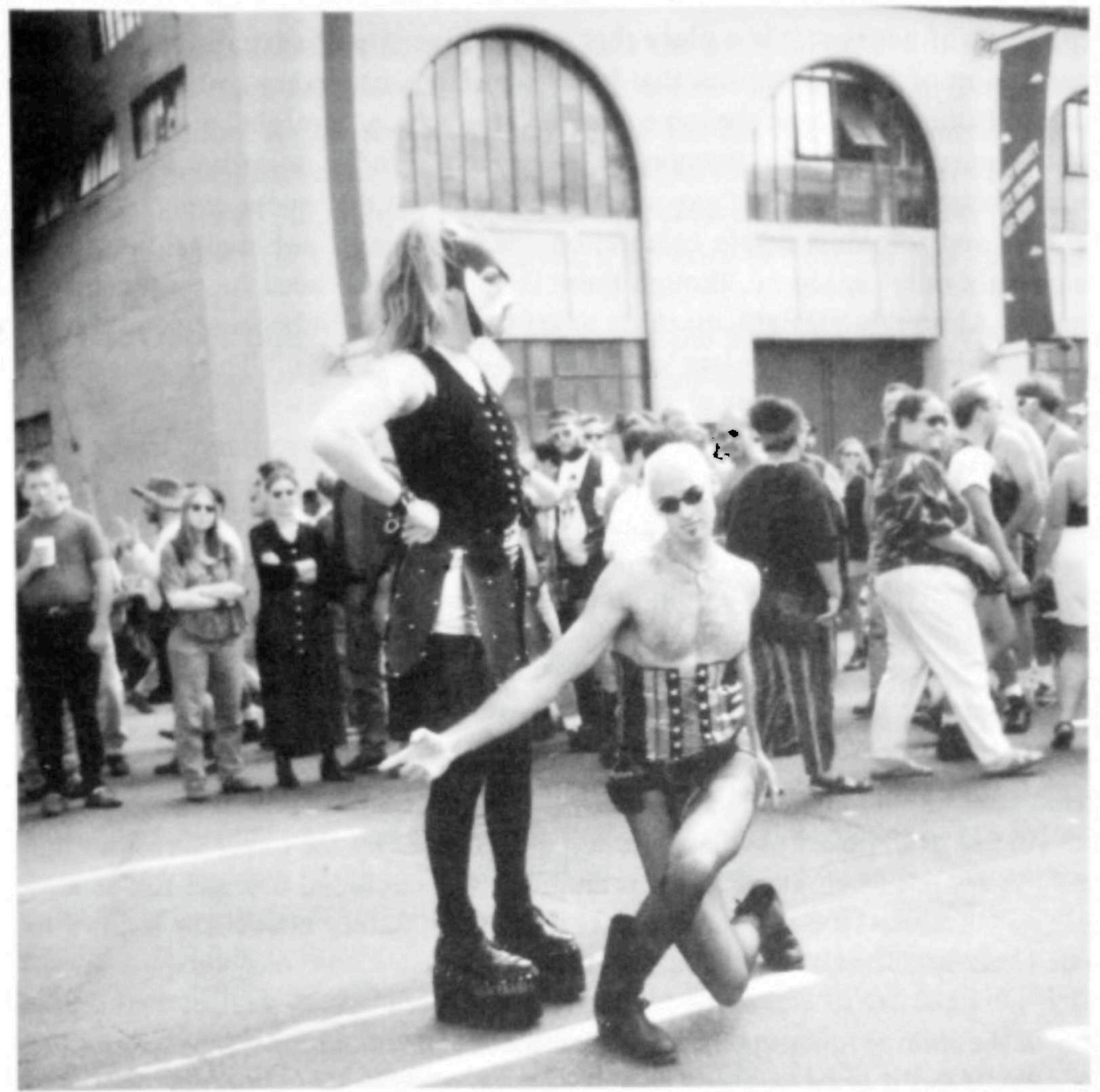

Figure 4

Playing out a leather lifestyle at the Folsom Street Fair, San Francisco, 1998.

at times it is unclear who is gazing at whom. Is the "straight" audience the active voyeur, or are queers, in fact, staring back at the "stratght other"? More over, can the audience be rightly characterized as entirely composed of "straights"? Probahly not. Feminist film theory has deconstructed the "male gaze," and many scholars have addressed the "colonial gaze" and the "whote gaze." However. a comprehensive analysis of both the "queer gaze" and the "stralght gaze" has yet to he produced.

In any event. gazing on a sexual "other" seems to constitule a part of the touristic experience for both "stratght" and queer fomrsts. The visually rich performances and ambiance at Josie's are explicitly concerned with queer issues. from overtly political one-act plays to decor made by $\mathrm{HIV}+$ people. ${ }^{35}$ The allure of a queer cafe, unapologetically "out" about its politics, is avalable to both queer and nonqueer visitors to the city. This suggests a second element in the construction of a queer homeland: that coalitions must be consciously built and maintained between queer and nonqueer people. Josic's is a safe place for 
a panoply of patrons; it is a place that hosts a diversity of sexualities. The representation of Josie's implies that heterogeneity is necessary to build a queer nation. Boundaries, here, become stretched to include "straight" allies.

Discussing the phenomenon of "gay space," Hodge describes the controversy about "straights" in "gay space" and suggests that queer events "should be first and foremost a safe celebration space for gays, not exclusionary like 'women's only' space ... though there is sometimes a need for exclusionary spaces. Although 'straight space' is never totally straight because gays are always present whether they are "out' about it or not" (1998). ${ }^{36}$ The construction of a "gay space," or "queer place," is complex and here includes nonqueer allies. Josie's is represented as a nonexclusive, though no less overt, queer hub. It is a place where sexualities mix, while its status as a political venue for queer people remains. Further, Josie's is not described as an exclusively "men's" or "women's" café but, instead; is represented as open to the play of various gender and sexual identities. Although the representation of Josie's is verifiably queer, the café is not represented as monolithically so. The polymorphous inclusivity of queer identity was well spoken by a female informant whom I interviewed at Josie's.

M. identified herself as a lesbian who had recently moved to San Francisco after having visited the city many times. She recalled with some nostalgia her first trips to the city, where she felt empowered by the queer surroundings and her sense of belonging to a community. $M$. concluded that she felt safe as an "out" lesbian in San Francisco. This sense of safety ultimately led her to place less emphasis on her sexual identity:

When I was in Minneapolis, and after I came out, I felt like I had to be so out all of the time. It's like I had to be superlesbian because the environment there was so different than here. I went to all the marches and rallies and was involved in organizations. It was all about being gay. Here, after a while, I just quit doing all that. Now I do political work with prison rights and animal rights. But it's like I don't have to highlight queer stuff so much anymore. So, in that way, I don $\mathrm{t}$ think I' $\mathrm{m}$ quite "as gay" now... . There I had to do dyke drag all the time, constantly proving that I was part of the community. I had to be a certain kind of lesbian: the white $T$. shirt, the jeans, the big black boots. So I think that San Francisco has allowed me to become a different kind of woman, I don 't have to fit the role of superdyke here. ... I can be me, a little more femme, and that's OK. [emphasis added] ${ }^{37}$

M.'s queer identity is here intimately linked with her political activism and gender identity. As she became less involved in queer politics, M. de-emphasized her sexual identity. In representing her identity. or as Butler (1990) might have it, "performing" her identity, M. associated queerness with political activism. Her "transformation" was not sexuality based but. rather. a gender transformation-"a different kind of woman"-intimately linked to her sexuality. M.'s words reflect that sexual identity in general. and queerness in particular, is a complex set of factors that includes shifting between various versions of the self. Her comments situate queer identity not as a monolithic essence but, rather, as a fluid set of meanings hinging on notions of sexuality and gender. 
Like the representation of Josie's, M. reflects the political aspect of queer nation building. Each representation denies the notion of an essential, exclusive, queer population. In this sense, $M$.'s discourse and the discourses surrounding Josie's suggest a particular kind of nationalist-like rhetoric, more akin to "cultural nationalism" (Chatterjee 1993) than that described by Anderson (1983). Rather than political control of the state, a network of "insider ties" coheres this queer nation.

Red Dora's Bearded Lady, on the fringe of the Mission District, is a regular rallying point for a preliminary ride by Dykes on Bikes on the eve of the Pink Saturday "Gay Day" Parade. Co-owned by a member of the notorious punk dyke band Tribe $8,{ }^{38}$ the café serves steamed eggs, unlimited coffee, and vegetarian hot dogs. It maintains a community bulletin board with an abundance of queer events and workshops and hosts poetry readings, musical events, and rotating shows of local artists' work. Red Dora's is listed as a "women's cafe" in queer tour books and does not appear in nonqueer guides to the city. I spoke with a female cashier, whom I call S., about her interaction with queer visitors to the city. ${ }^{39}$ She explained that queer tourists were very easy to recognize: "You know when they are a tourist because they are overwhelmed by the menu and can never decide ... and they buy everything: the $T$ shirts, and sweatshirts, and postcards, and everything. I guess they want to show everyone back home in Iowa that they were here and went to the cool gay spots." ${ }^{\star 10} \mathrm{~S}$.'s comment reflects the stereotype of tourist-dupes who are never quite comfortable in their surroundings; it also emphasizes the "insider' $s$ " acumen in recognizing queer "interlopers." Further, she refers to the consumption of queer "markers," which Red Dora's is in the business of providing. Though Red Dora's does not sell rainbow flags or pink triangle bumper stickers, it does market the punky equivalent: T-shirts that say, "I may not go down in history, but I'll go down on your sister," or a play on dive bar rhetoric, "Liquor in the front. Poker in the rear." S. seemed to relay an antipathy for queer tourists who want to buy some form of identity, a shallow reflection of themselves, that can be bandied around back home. Iowa, in her estimation, is figured as a place where one must wear one's identity; San Francisco is the place to procure this "identity." Consumption then validates and marks the "experience" of the pilgrimage. In contrast, residents of the city, "insiders," are expected to manifest some "authentic" queer self without the aid of trite symbols. Perhaps being a queer resident of the city, as opposed to a mere visitor, one is supposed to live an "essential" queer identity that is not dependent on queer trappings. Residents of the city may thus avoid purchasing "touristic" queer markers in order to avoid being mistaken for anything but "authentic" queer San Franciscans. Shenhav-Keller (1995) addresises a similar phenomenon in her analysis of purchases made by tourists in Tel Aviv's popular Maskit store. Tourists, anxious to bolster their sense of Jewish identity, actively seek the most "authentic" representations available. Residents, however, rarely purchase these icons, presumably because they are comfortable with their own "authentic" identity by 
virtue of residing in a Jewish state. In sum, it appears as though "insider" (Boissevain 1996) status precludes overt identity markings, queer ur Jewish.

In the introduction to Gay USA (1995), Hobica suggests a further disruption of bounded and easily marked identity categories. He writes that in San Francisco, "unlike Boston, people don't care what you do-they don't judge. You can be a lesbian one day, bi the next and heterosexual and married a week later and no one bats an eyelash" (1995:184). ${ }^{41}$ Hobica emphasizes that San Francisco, as a place, allows people to move between and among particular identities. The fluidity he describes echoes recent debates about the use of "identity tags," which some argue limit subjectivity (Butler 1997) and obscure the heterogeneity of queerness (Anzaldúa 1991). S.'s words and those of the tour book suggest that San Francisco allows a range of sexual identity choices not available in other places. Not only can one easily choose a sexual identity, but this identity can also be easily traded in for a new one. Unlike Boston's or perhaps Iowa's, San Francisco's cultural climate does not insist on the maintenance of strict identity categories. In other words, a queer homeland provides choice in regard to sexual identities, and these identities are flexible and changeable over time; even through shifts of sexual identity, one can retain an "authentic" queer self.

These discourses of authenticity are reminiscent of Goffman's front- and backstages, where the authentic backstage is accessible only to locals, who guard the mystique of essential identities. In the case of San Francisco, however, the "authentic" queer self is enhanced by rejecting identity labels and the overt symbols of queerness: identity markers based on circumscribed categories. I would add that this ability to remain "unmarked" while still retaining an "out" queer identity is only possible in places where queer activism and a high tolerance for "alternative lifestyles" have prevailed over time. In those places where it is dangerous to be marked as queer, there is no luxury of choice. Rich's (1986) "compulsory heterosexuality" is perhaps "queered" in San Francisco to become a form of sexual fluidity. However, this inversion is possible only after heteronormativity has been disrupted to some degree. San Francisco. in this sense, is represented as a place, unlike most places on the planet. where one can "play" with sexual identity tropes. One need not take a one-dimensional stand on the sexual self.

\section{Conclusion: A Homeland Halfway to the Stars}

Guidebooks that routinely boast that San Francisco is "the gayest city in the United States" and "gay central USA" reflect many of the sentiments expressed by queer tourists in search of a homeland. San Francisco becomes constructed as a pilgrimage site for the elaboration of queer identity through emerging discourses that, though sometimes "essentialized," are continually in a state of negotiation-a negotiation that takes place between "insiders" and "outsiders" and within the rubric of "queer" itself. Queer pilgrimage does not conform to a homogeneous sense of queer identity but, rather. is mediated by other factors such as race, class status. age. and gender. Thus. queerness as an 
identity construct reveals itself to be flexible, fluid, and open to shifts in meaning even when queerness is employed in the very concrete process of territorializing a homeland. Unlike many trends within identity politics, the imagining of a queer nation, with a homeland located in San Francisco, suggests new avenues for articulating identity. I have argued that San Francisco does serve as an imagined homeland for queers, a nexus point for the "ideoscape" (Appadurai 1996) of a queer imaginary. However, I have also elaborated how representations of the city include a flexible set of identities, rather than a singular emphasis on a one-dimensional queer subject. The city operates as a transnational mecca for queer tourists only on the condition that it not restrict too drastically its definition of "queerness."

Nationalist-like tropes, deployed to consolidate a queer nation, are ubiquitous in the ethnographic narratives I encountered in San Francisco. Although it would be unwise to configure a queer nation as exactly equivalent to other nationalist projects, it would be equally problematic to discount the efficacy of nationalist-like discourses. It is, after all, no coincidence that the largest flagpole in the city is erected in the Castro and flies the rainbow flag. The proliferation of nationalisms around the globe underscores the need to better understand diverse articulations of nationalist-like endeavors. In particular, forms of nationalist-like sentiments that do not rely on the "imagined" ties of blood, bone, and cultural patrimony may suggest new ways of conceptualizing peoplehood based on different criteria, such as sexuality.

My intention has been to emphasize that a queer homeland may be both logically and ethically tied to touristic practices. If all of the "back homes" offered the "playing and praying" possible in San Francisco, the city might not exist as a point of queer concentration. The "mundane social life" outside of the mecca stands in stark contrast to the symbolic inversion possible in a queer homeland. Although all pilgrimages involve leaving "home" to find spiritual redemption, the unique quality of queer tourism is that a reversal of religious pilgrimage is at play. Many queer tourists leave home because it is there that they have undergone spiritual exile; a "homeland" offers the sanctuary that many "back homes" do not. Pilgrimage to San Francisco also raises the question of whether having a place for queer liminality forecloses the need to effect change in the status quo back "home." The construction of a queer homeland may thus be politically dangerous, providing a "ghetto" for the banished. Whatever the political ramifications may be, the path to a homeland seems to be built on sex and politics. San Francisco's history of nonconformity is critical here too, for neither sex nor politics prefigures a sense of peoplehood; these phenomena have occurred in other places at other times without ever creating a mecca. By gazing at and through the queer tourist, it is clear that the construction of a queer homeland is a complex and rich terrain. Through these multiple aspects of identity migration, many queers have left their hearts in San Francisco, and a homeland is still in the process of being imagined. 


\section{Notes}

Acknowledgments. This article has benefited from the thoughtful feedback of Sylvia Rodriguez, Les W. Field, and James Quesada, all of whom I thank for their support and insights. I also acknowledge the comments made by Daniel A. Segal and the anonymous reviewers for $C A$, whose suggestions I found useful in developing this essay. Earlier versions of this article were presented at the American Anthropological Association meeting in Philadelphia in December 1998 and at the American Ethnological Association meeting in Portland, Oregon, in March 1999. For their comments at these meetings, I would like to thank Ellen Lewin and Louise Lamphere. My thanks go out to the graduate students at the University of New Mexico, whose enthusiasm about this project has helped to make it a reality. I also thank all of the people I interviewed and hope that I have managed to let their queered selves shine through.

1. "Ephemera," such as flyers, posters, and brochures, are transient in nature, ever changing, unarchived, and quickly disposed of. In the context of ephemeral things, I would like to highlight the likewise transient and ever changing discourse that appears in this discussion. The tour guidebooks I have examined use, for the most part, the terms gay and lesbian rather than queer. Thus, these guides seem to be "oriented," or marketed, to lesbians and gays rather than "queers." However, I have chosen to elaborate on a notion of a specifically "queer homeland" rather than a "gay and lesbian homeland" because of the inclusivity of "queer" identity (bisexuals, sexual radicals, etc.), which I hope to demonstrate is fundamental to the construction of a homeland in San Francisco. Overall, there is a movement among the terminology of respondents' narratives, the language of tour books, and the conceptual framework of "queerness," creating a dynamic tension that mirrors the complexity of articulating a sense of homeland.

2. My use of " $\mathrm{a}$ " queer nation is distinct from the political organization Queer $\mathrm{Na}$ tion started in April 1990 by a group of AIDS Coalition to Unleash Power, or ACT UP, organizers interested in direct actions that would address a broader range of gay and lesbian issues.

3. Tourism is considered a "privileged practice" because economic status often determines who can, or cannot, engage in touristic endeavors. Further, the practice of pilgrimage, according to the Turners (1978), arose with the dominant world religions, most of which denigrate homosexuality. Tracing the pilgrimage qualities of gays and lesbians going to San Francisco serves to upset the correlation of pilgrimage with dominant and exclusionary religions. Rather, a pilgrimage to a gay homeland might be construed as overtly anti"religious."

4. I follow Rothman's suggestion that tourism sells "ambiance, experience, and identity ... [an exchange that] is more complicated and ambiguous than a material sales transaction. A feeling is transmitted and perhaps shared; a way of living is expressed" (1998:20).

5. Rothman (1998:16) maintains that "cosmopolitan, urban, affluent" coastal cities, such as San Francisco and Los Angeles, "reflexively" cater to tourism and that this tourism has taken on a form distinct from that in other places in the United States where tourism has developed.

6. Weston describes the "gay imaginary" as a participatory process wherein "the designation of lesbians and gay men as 'a people' becomes bound up with the search for sexual partners and the construction of a lesbian or gay identity" (1998:34). In other words, the "gay imaginary" does not require finding one's essential gay self but, rather, subjectivity is constructed through imagining a "we-ness." Weston contends that this imagining is generated in the urban centers where gay migrations have occurred. 
7. Bean explains that "the Indian death rate was accelerated" (1968:169), primarily because of disease and starvation, as hundreds of thousands of "Americans" migrated to California. A Native American population of 30,000 in 1870 was reduced to less than 16,000 by 1900 (Bean 1968:169).

8. The development of railroads, according to Rothman (1998:47), also increased the number of resorts in the San Francisco and Monterey Bay areas, thus linking industrial expansion and touristic endeavors.

9. See Bean 1968:235-243 for a discussion of the complexities among the Workingmen's Party, California employers, and the federal government on the issue of Chinese immigrant labor.

10. The early 1950s were the time of the "San Francisco Renaissance," marked by the establishment of the Poetry Center at San Francisco State (Bean 1968:448). The beat literary movement that followed soon after has been described as a combination of a retreat from the "modern" East Coast and a seeking of "individuality" (Rothman 1998:167) that was centered in San Francisco.

11. Mona's, an all-women's bar, first opened in 1936 and catered primarily to working-class women, though middle-class lesbians vacationing in San Francisco also spent time there (Faderman 1991:107). In 1950, Mattachine, a homosexual organization begun by five gay men who had been members of the Communist Party, was active in San Francisco. Two years later, Del Martin and Phyllis Lyon would establish the first alllesbian organization, the Daughters of Bilitis.

12. Once a significant number of queer people had moved to the Castro and created an enclave community, their numbers continued to increase. Stephen O. Murray (1992) suggests that homosexual residential concentration and the recreational facilities that followed created a sense of community and shared experience. He goes on to describe how the development of the welfare state allowed individual gay people to move to enclave communities as they were freed from economic dependence on their families/communities of origin. However, I would add that other social factors, such as the "queer ships" noted earlier, added to the phenomenon of enclave communities.

13. Likewise, Kennedy and Davis suggest that because San Francisco was a "cosmopolitan" city, "it had the numbers to generate the politically conscious leadership of the homophile movement" (1993:115). Further, Stein (1997) finds the growth of feminist culture to be rooted in the lesbian movement that was generated through lesbian bar scenes, alternative families, and woman-centered ideals found in San Francisco from the 1970 s to the 1990 s.

14. Harvey Milk's election to the Board of Supervisors was applauded by the gay men living in the Castro who had formed the backbone of Milk's campaign. Milk's murder in 1978 and the acquittal of his assassin, Dan White (with the infamous "Twinkie defense"), caused a profound shudder in the gay quarter of the city.

15. I am not suggesting that sexual "orientation" is chosen but, rather, that one may choose to include oneself in a larger whole of queer "nationhood."

16. The notion of "chosen" membership in a queer nation is contentious. Historically, homosexuality has been understood, variously, as "innate"/biological or a product of socialization. Foucault (1978) has also described the social construction of the term in a historical process meant to mark certain people as "other." However, in the sense that one can choose to be "out" or not, one chooses to include oneself in a queer nation. Similarly, the feminist movement in the early 1970s advocated "voluntary" lesbianism as a way to consolidate separatist power. The more recent use of queer, which includes 
nongay/nonlesbian-identified allies, certainly speaks to the chosen nature of queer nation membership.

17. Bourdieu (1980) distinguishes critical thought from ordinary perception and activity from reflection. "Leisure" or "play" is, then, a function of privilege. My use of play here is more flexible than that suggested by Bourdieu. "Play" functions as active participation in a queer community rather than solely a practice of one's cultural capital.

18. Judith Butler (1993) has suggested that play constitutes "the matrix of identity" as players, after play, make community - much as ritual leaves in its wake "a community of believers" (Lancaster 1997:24).

19. Interview with "L.," conducted at the San Francisco Pride Parade, June 1998. L. was a 31-year-old self-identified Latina bisexual originally from Dallas who lived in Los Angeles and worked as an administrative assistant. Our interview was brief because of the context of the festivities, crowds, and so on. The brevity of this interview, however, highlights the difficulty of conducting research on gay and lesbian topics within anthropology. While funding sources are limited for many anthropological research endeavors, the lack of funding available for queer research may be particularly pronounced, thus limiting researchers' ability to conduct extensive ethnographic projects.

20. Discussing a related phenomenon in heterosexual "sex tourism," Tucker notes that "tourism clearly influences power in sexual identity and presents opportunities that may be perceived as lacking in the tourist's home environment" (1997:114), suggesting that transformations through sex(uality) tourism occur within queer and "straight" encounters.

21. Interview with 'Z.," conducted at Red Dora's Bearded Lady Cafe, June 1988. Z. was a 32-year-old self-identified white lesbian living in Reno, Nevada, who did freelance graphic design work and frequented San Francisco, her former home.

22. Interview with "J.," conducted at the San Francisco Pride Parade, June 1998. J. was a 40-year-old male, self-identified as white and homosexual, who worked as a waiter in Hamburg, Germany.

23. Interview with "O.," conducted at the San Francisco Pride Parade, June 1998. O. was a 23-year-old male who self-identified as a black gay man. $O$. lived in Atlanta. Georgia, his birthplace, and worked as a financial consultant.

24. This respondent's use of "my people" is particularly interesting given that he was a German tourist who was, in San Francisco, far outside the borders of his own nation-state. Further, "my people" is reminiscent of the use of Volk to consolidate a sense of nationalist pride. Here, gay people are configured as the "Volk," which seems to invert the reproductive, blood ties of the German nationalist "Volk."

25. "Pride" parades and events have become ubiquitous in many U.S. cities and abroad, which suggests, perhaps, that the Pride Parade in San Francisco is just another example of this trend. However, I maintain throughout this article that the particular qualities of San Francisco as a site of identity construction, rooted in history, politics, and so forth, make the San Francisco Pride events unique and exemplify the qualities of a homeland.

26. See Shenhav-Keller 1995 for a discussion of Jewish pilgrimage to Isreal, where a parallel dynamic seems to occur: a journey "back" to a "home"land that one has never been to before. Both experiences, queer and Jewish pilgrimage, serve to disrupt easy definitions of "home" as a place of material, geographic familiarity. Rather, a homeland is a composite of symbolic and material factors: a place of we-ness, sanctuary, historical relevance, and so on. 
27. Cafe Flore is well known as a "cruising" place for gay men in the Castro, where one's ability to coif correctly may mean the difference between a date or not. I believe that the sexualized atmosphere at Cafe Flore alongside a playful appropriation of stereotypes about gay men's vanity are the origins of the nickname "Cafe Hairdoo." However, as with all cultural products that arise in subcultures, there are no doubt multiple interpretations of the meaning of "Cafe Hairdoo."

28. This particular guide is distinct from others in that it reflects San Francisco's representation of "itself." It is not a commercial guide from "outside" the city.

29. The economic differences between the Castro and the Mission are significant here as well. In general, rents are less in the Mission District than in the Castro, and the income levels of residents in each neighborhood seem to correspond to this fact. Commercial venues in the Castro, for example, have tended to be more costly than those in the Mission, although this has changed in recent years as the Mission District has become gentrified.

30. This debate arose sporadically while I was active in the 1995 Dyke March planning sessions. The question never reached the level of an official agenda item in the meetings, but it was bandied about as a point of contention. In comparison with the Michigan Women's Music Festival, where the debate about (specifically male-to-female) transgender inclusion has been volatile, Dyke March concerns about transgender inclusion have been far less controversial and divisive.

31. Interview, conducted at the Dyke March, June 1998, with a 29-year-old woman who self-identified as a Jewish lesbian.

32. Here I take the position that "young men on drugs" are unmarked in comparison with racial "others" who are explicitly marked by race in the text I am assessing. However, it is important to note that often, in popular media and in stereotyping discourses, men of color are portrayed as "on drugs." I do not believe that to be the case in this particular instance, but I do acknowledge that this pervasive and damaging stereotype may be a factor in how the text of this guidebook is interpreted by readers.

33. California: Culture's Edge (CCTC 1998) comprises 12 different tours in the cities of San Francisco, San Diego, and Los Angeles. Consensus had to be reached on which 12 tours to include because each city was responsible for providing one tour within the stated categories. In other words, all three cities have showcased tours such as "Jewish Heritage," "Fiesta," "Mission Trail," “Jazz and Blues," and so on. Apparently, the San Diego board felt it did not have enough "Pride" sites within the city and so advocated that "Pride" not be one of the tours. Whether or not this was the actual reason the San Diego board contested the "Pride" tour is, of course, questionable. The publication was funded, in large part, by the National Endowment for the Arts, whose acceptance of homosexuality and sex-positive images has not been exemplary. Perhaps a feared loss of funding influenced the conclusions of the San Diego tourism board.

34. Though Josie's is not marked explicitly in nonqueer guides as a queer venue, the lists of events and descriptions of Josie's in these guides do emphasize a nonheterosexual environment.

35. Urvashi Vaid (1995) suggests that AIDS had the effect of "outing everyone" because gay and bisexual men were dying in such large numbers in the first years of the epidemic. The queer community significantly shifted focus as energies previously spent on organizing for queer rights were now needed to combat AIDS, raise awareness, promote research, and so on. The nature of politics in the queer community underwent and continues to undergo significant changes. Vaid further suggests that the AIDS epidemic forced the queer political community to revision its goals, from a "liberation" model to 
a "legitimation" model. Because the medical needs around AIDS are so great, queer organizers have needed to call on "the straight world" for assistance. This shift to obtain "conditional equality" was, according to Vaid, initiated by the AIDS crisis.

36. Michael Bronski (1984) makes a similar claim in his assertion that much of what is called "straight" culture is heavily infused with a gay sensibility: ballet, opera. Broadway, theater, art, and film have all been shaped by the talents of gay men. A similar sentiment is reflected in the film The Celluloid Closet (1996), created by two San Francisco gay men.

37. Interview with "M.," conducted at the Lexington Club, June 1998. M. lived in San Francisco and worked as a firefighter. She is identified as a white lesbian and was 33 years old. For detailed discussions of the distinctions between "butch" and "femme," see Case 1993, Kennedy and Davis 1993, and Stein 1997.

38. "Tribe 8" has a similar pronunciation to tribade, which, according to the $O x$ ford English Dictionary, is "a woman who practices unnatural vice with another woman."

39. "S." did not mention nonqueer tourists during our discussion.

40. Interview with "S.," conducted at Red Dora's Bearded Lady Cafe, June 1998. S. worked at the cafe, lived nearby, and identified herself as a Jewish dyke. She is originally from Kansas.

41. It seems to me that this progression from "lesbian," to "bi," to "hetero," to "married" is not accidental. The issue of bisexuality has been raised as a concern within San Francisco queer communities. Are bisexuals "authentically" queer? Can they be trusted as political allies and potential bedfellows? More recently, however, one hears more and more about "hasbians" (former lesbians now involved in significant relationships with men). As one woman ironically put it, "Lesbians these days! If they're not sleeping with men, they're becoming men."

\section{References Cited}

Anderson, Benedict

1983 Imagined Communities: Reflections on the Origin and Spread of Nationalism.

London: Verso.

Anonymous

1998 Review of Fodor's Gay Guide to the USA. Electronic document, http://www. amazon.com, accessed November 22.

Anzaldúa, Gloria

1987 Borderlands/La Frontera: The New Mestiza. San Francisco: Aunt Lute Books.

1991 To(o) Queer the Writer: Loca, escrita y chicana. In InVersions: Writing by

Dykes, Queers and Lesbians. Betsy Warland, ed. Pp. 249-263. Vancouver: Press Gang. Apell, David, ed.

1998 Access: Gay USA. New York: Access Press.

Appadurai, Arjun

1996 Modernity at Large: Cultural Dimensions of Globalization. Minneapolis: Uni-

versity of Minnesota Press.

Bean, Walton

1968 California: An Interpretive History. 2nd edition. New York: McGraw-Hill. Bérube, Allan

1982 Past Times: Unearthing the History of Gay G.I.s. Chicago Reader 11 (June 18):36. 
Boissevain, Jeremy, ed.

1996 Coping with Tourists: European Reactions to Mass Tourism. Providence, RI: Berghahn Books.

Boorstin, Daniel J.

1964 From Traveler to Tourist: The Lost Art of Travel. In The Image: A Guide to

Pseudo-Events in America. Pp. 77-117. New York: Antheneum.

Bourdieu, Pierre

1980 The Logic of Practice. Stanford: Stanford University Press.

Bronski, Michael

1984 Culture Clash: The Making of Gay Sensibility. Boston: South End Press.

Bruner, Edward

1991 Transformation of the Self in Tourism. Annals of Tourism Research 18:

238-250.

Butler, Judith

1990 Gender Trouble: Feminism and the Subversion of Identity. New York: Routledge.

1993 Bodies that Matter: On the Discursive Limits of "Sex." New York: Routledge.

1997 Excitable Speech: A Politics of the Performative. New York: Routledge.

California Cultural Tourism Commission

1998 California: Culture's Edge. Los Angeles: California Cultural Tourism Commission.

Case, Sue Ellen

1993 Toward a Butch-Femme Aesthetic. In The Lesbian and Gay Studies Reader.

Henry Abelove, Michèle Aina Barale, and David M. Halperin, eds. Pp. 294-306.

New York: Routledge.

Castañeda, Quetzil E.

1996 In the Museum of Maya Culture: Touring Chichén Itzá. Minneapolis: Univer-

sity of Minnesota Press.

The Celluloid Closet

1996 Robert Epstein and Jeffrey Friedman, dirs. $102 \mathrm{~min}$.

Chatterjee, Partha

1993 The Nation and Its Fragments: Colonial and Postcolonial Histories. Princeton:

Princeton University Press.

Clifford, James, and George Marcus, eds.

1986 Writing Culture: The Poetics and Politics of Ethnography. Berkeley: University of California Press.

Collins, Andrew, ed.

1997 Fodor's Gay Guide to the USA. New York: Fodor's Travel Publications.

Dahles, Heidi

1996 The Social Construction of Mokum: Tourism and the Quest for Local Identity

in Amsterdam. In Coping with Tourists: European Reactions to Mass Tourism.

Jeremy Boissevain, ed. Pp. 227-246. Providence, RI: Berghahn Books.

de Certeau, Michel

1984 The Practice of Everyday Life. Minneapolis: University of Minnesota Press.

Faderman, Lillian

1991 Odd Girls and Twilight Lovers: A History of Lesbian Life in Twentieth-Century America. New York: Penguin Books. 
Fitzgerald, Frances

1986 Cities on a Hill: A Journey through Contemporary American Cultures. New

York: Simon and Schuster.

Foucault, Michel

1978 The History of Sexuality, vol. 1. An Introduction. Robert Hurley, trans. New

York: Vintage Books.

Goffman, Erving

1959 The Presentation of Self in Everyday Life. Garden City, NY: Doubleday.

Graburn, Nelson $\mathrm{H}$.

1989 The Sacred Journey. In Hosts and Guests. Valene Smith, ed. Pp. 21-36. Philadelphia: University of Pennsylvania Press.

Hobica, George

1995 Gay USA: The Straight Talking Guide to Gay Travel. Chicago: First Books.

Hodge, Steven

1998 This Way Out Radio Broadcast: Gay Space in Sydney's Mardi Gras. National

Public Radio, Sydney, October 11.

Irvine, Janice $M$.

1998 A Place in the Rainbow: Theorizing Lesbian and Gay Culture. In Social Perspectives in Lesbian and Gay Studies. Peter Nardi and Beth E. Schneider, eds. Pp. 573-588. London: Routledge.

Kaplan, Caren

1996 This Question of Moving. In Questions of Travel: Postmodern Discourses of

Displacement. Caren Kaplan, ed. Pp. 27-64. Durham: Duke University Press.

Kennedy, Elizabeth Lapovsky, and Madeline D. Davis

1993 Boots of Leather, Slippers of Gold: The History of a Lesbian Community. New

York: Penguin Books.

Lancaster, Roger N.

1997 Guto's Performance: Notes on the Transvestism of Everyday Life. In Sex and

Sexuality in Latin America. Daniel Balderston and Donna J. Guy, eds. Pp. 9-32.

New York: New York University Press.

Lanfant, Marie-Françoise, John B. Allock, and Edward M. Bruner, eds..

1995 International Tourism: Identity and Change. London: Sage.

MacCannell, Dean

1976 The Tourist: A New Theory of the Leisure Class. New York: Schocken Books. Murray, Stephen $O$.

1992 The "Underdevelopment" of Modern/Gay Homosexuality in MesoAmerica. In Modern Homosexualities: Fragments of Lesbian and Gay Experience. Ken Plummer, ed. Pp. 29-38. London: Routledge.

Newton, Esther

1993 Cherry Grove, Fire Island: Sixty Years in America's First Gay and Lesbian

Town. Boston: Beacon Press.

Phelan, Shane, ed.

1997 Playing with Fire: Queer Politics, Queer Theories. New York: Routledge.

Rich, Adrienne

1986 Compulsory Heterosexuality and Lesbian Existence. In Blood, Bread, and Po-

etry: Selected Prose, 1979-1985. Pp. 23-68. New York: W. W. Norton.

Rothman, Hal K.

1998 Devil's Bargains: Tourism in the Twentieth-Century American West.

Lawrence: University Press of Kansas. 
Shenhav-Keller, Shelly

1995 The Jewish Pilgrim and the Purchase of a Souvenir in Isreal. In International

Tourism: Identity and Change. Marie-Françoise Lanfant, John B. Allock and Edward M. Bruner, eds. Pp. 143-158. London: Sage.

Stein, Arlene

1997 Sex and Sensibility: Stories of a Lesbian Generation. Berkeley: University of California Press.

Towner, John

1985 The Grand Tour: A Key Phase in the History of Tourism. Annals of Tourism Research 12:297-333.

Tucker, Hazel

1997 The Ideal Village: Interactions through Tourism in Central Anatolia In Tourists and Tourism: Identifying with People and Places. Simone Abram, Jacqueline Waldren, and Donald V. MacLeod, eds. Pp. 107-128. Oxford: Berg.

Turner, Victor, and Edith Turner .

1978 Introduction: Pilgrimage as a Liminoid Phenomenon. In Image and Pilgrimage in Christian Culture. Victor Turner and Edith Turner, eds. Pp. 1-39. New York: Columbia University Press.

Uny, John

1990 The Tourist Gaze: Leisure and Travel in Contemporary Societies. London: Sage Publications.

Vaid, Urvashi 1995 Virtual Equality: The Mainstreaming of Gay and Lesbian Liberation. New York: Anchor Books.

Weston, Kath

1998 Long Slow Burn: Sexuality and Social Science. New York: Routledge.

Williams, Brackette

1996 Women Out of Place: The Gender of Agency and the Race of Nationality. New York: Routledge. 